\title{
Pioneer in QOL Research: Van Praag
}

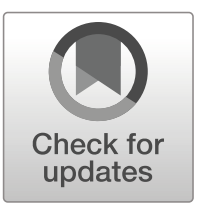

\section{Bernard M. S. van Praag ${ }^{1}$}

Published online: 31 July 2020

(C) The International Society for Quality-of-Life Studies (ISQOLS) and Springer Nature B.V. 2020

I was born in Amsterdam in 1939. In 1956, I enrolled at the University of Amsterdam (UvA) to study Economics and Actuarial Sciences. When I received my bachelors, I switched to Econometrics, which had just started as a specific curriculum. In 1964, I was awarded a Master's (cum laude) and began working as a research associate with Henri Theil at the Econometric Institute of the Netherlands School of Economics (now Erasmus University) at Rotterdam. I got my Ph.D. (cum laude) at Amsterdam in 1968. In 1972, I was appointed full professor of Economics at Leyden University. In 1984, I became a Professor of Mathematical Economics in Rotterdam, and in 1992, I went to Amsterdam as the Director of SEO Amsterdam Economics, a university-affiliated research institute. In 2001, I was appointed as a Distinguished University Professor of Amsterdam University and in 2004, I retired.

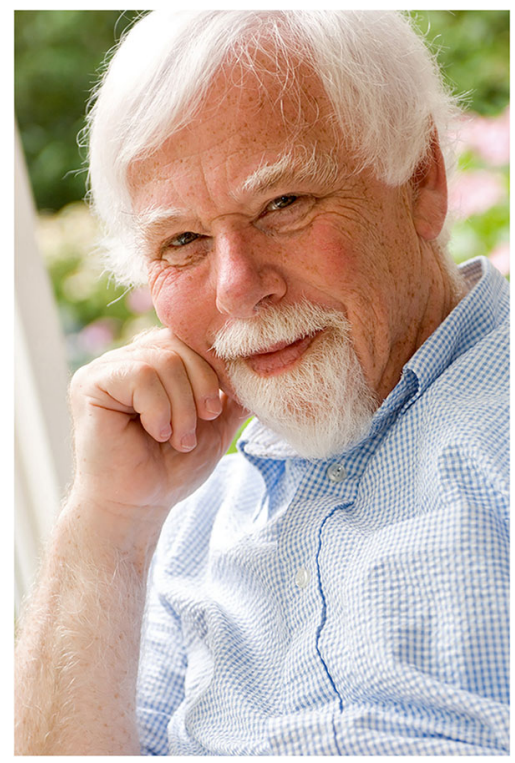

Bernard M. S. van Praag

B.M.S.vanPraag@uva.nl

1 University of Amsterdam, Tinbergen Institute, Amsterdam, Netherlands 
During my study of Economics, I was in a state of steady confusion about the real significance of economic science. In the early Sixties and certainly in Europe, economics was still in its infant days. Research was focused on theoretical models. After my study, my attention was drawn to Tinbergen's work, which seemed to me a breakthrough towards reality. One of the points that struck me as being unrealistic was the approach of utility as an ordinal concept. In my Ph.D. dissertation (Van Praag, 1968), I defended cardinal utility as a realistic concept, based on the empirical observation that individuals are able to evaluate any aspect of life. For example, a bottle of wine, their income, or their life as a whole - on a bounded scale, say, between 0 and 1 , where 0 stands for the worst and 1 for the best situation conceivable. This socalled Evaluation Assumption strongly suggests a distribution function, formally isomorphic to a probability distribution function, as a functional specification of a utility function. In Van Praag (1968), I suggested the lognormal distribution function as specification of a utility function of income. In those days, for nearly all economists this was heresy. In order to navigate my way out of this fruitless discussion, I looked for other new terms and I coined the concept Individual Welfare Function of Income (IWF). However, at that time my ideas were not tested against empirical figures.

The first occasion for testing arose in 1970 when I could insert a few questions into a large survey questionnaire among members of the Belgian Consumer Union. I should remind the reader that at this point in time, the use of large-scale surveys among economists was practically unheard of.

The new question module was what I called the Income Evaluation Question (IEQ). The original version looked like this.

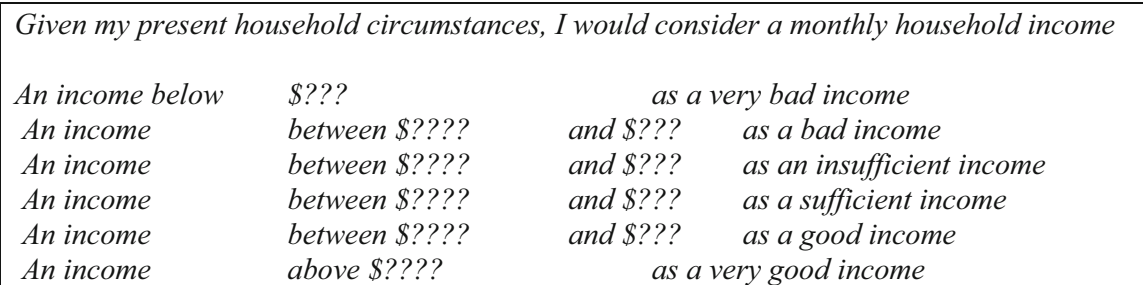

In hindsight, it may be seen as presenting six one-dimensional income vignettes ('very bad', 'bad', ... etc.) to the respondent, who responds by giving income estimates corresponding to the verbal qualifications.

In Van Praag (1971), I analyzed 2789 observations from the Belgian survey and it was found that such subjective questions, contrary to the predictions of most of my contemporaneous colleagues, could be responded to, and that after some transformation, the answers indeed confirmed the hypothesis that IWF's followed the lognormal shape pretty well. Moreover, it was found that the two lognormal parameters $\mu$ and $\sigma$ could be interpreted and that they varied per individual. We observe that this IWF should not be confused with the usual financial satisfaction question. The financial satisfaction question only asks for the financial satisfaction with own experienced income, while the IWF reflects the evaluation of all income levels by the individual.

The parameter $\mu$ could be rather well explained by the respondent's own income $y^{*}$. This observation reveals that the way in which an individual evaluates specific income 
levels of $y$ depends on his own income $y^{*}$, in formula $U(y ; y *)$. This is the translation of the rather trivial psychological connotation that someone with an income of $\$ 30,000$ will evaluate an annual income of $\$ 100,000$ as 'excellent,' while the individual with an income of $\$ 100,000$ will experience that same income as only 'sufficient'. I called this phenomenon the 'preference drift' and quantitatively estimated it. At the same time, the psychologists Brickman and Campbell independently coined the same effect "the hedonic treadmill' in their essay "Hedonic Relativism and Planning the Good Society" (1971). However, they did not give a quantitative estimate of the effect. In the same paper I found a family size-effect, implying that larger families needed more income to reach the same welfare level as smaller families. This resulted in the estimation of (subjective) family-equivalence scales (see Van Praag and Kapteyn 1973; Kapteyn and Van Praag 1976). In 1977, with this method we defined the subjective poverty line. We chose a specific welfare level as corresponding to the feeling of poverty, e.g., $U=0.4$. Then we could see that solving the equation $U(y ; y *)=0.4$ yields a poverty line $y_{\text {poor }}(y *)$. This implied that every individual has his/her own poverty concept. The subjective (or Leyden) poverty line was then the solution of $U(y * ; y *)=0.4$.

The equivalence-scale approach was also applied to the climate of Europe and for Russia (see Van Praag 1988, and Frijters and Van Praag 1998). The approach was also used to estimate the monetary value of a Quality Adjusted Life Year (QALY) by Ferrer-i-Carbonell and Van Praag (2002) and for the evaluation of external environmental effects in Van Praag and Baarsma (2005) and in Van Praag, Ferrer-i-Carbonell (2004). Similar questions to the IEQ, viz., with respect to the subjective evaluation of 'age' and 'length of education' were posed by Van Praag et al. (1988), shedding light on what is considered 'old' and 'young' or 'low' versus 'high'-educated.

In later studies, I followed the modern trend in happiness economics and looked also at the evaluation of life-as-a-whole, say, happiness, where one of its causal factors is monetary income. We studied this wider concept in Van Praag et al. (2003), Van Praag, Ferrer-i-Carbonell (2004, 2007), Van Praag and Ferrer-i-Carbonell (2010) where we considered financial satisfaction as one of the domains of life. Overall, well-being is then an aggregate of the partial satisfaction of various domains of life, like health, job, marriage, etc. Apart from the subject of welfare and happiness I published on other subjects, in particular on econometrics and the labor market. At present I am mainly working on pensions and social security.

\section{References}

Ferrer-i-Carbonell, A., \& Van Praag, B. M. S. (2002). The subjective costs of health losses due to chronic diseases. An alternative model for monetary appraisal. Health Economics, 11(8), 709-722.

Frijters, P., \& Van Praag, B. M. S. (1998). The effects of climate on welfare and well-being in Russia. Climatic Change, 39(1), 61-81.

Kapteyn, A., \& Van Praag, B. M. S. (1976). A new approach to the construction of family equivalence scales. European Economic Review, 7(4), 313-335.

Van Praag, B.M. (1968). The Probability Space as a Model of Welfare Evaluation. Netherlands School of Economics, Econometric Institute.

Van Praag, B. M. S. (1971). The welfare function of income in Belgium: An empirical investigation. European Economic Review, 2(3), 337-369.

Van Praag, B. M. S. (1988). Climate equivalence scales: An application of a general method. European Economic Review, 32(4), 1019-1024. 
Van Praag, B. M. S., \& Baarsma, B. E. (2005). Using happiness surveys to value intangibles: The case of airport noise. The Economic Journal, 115(500), 224-246.

Van Praag, B. M. S., Dubnoff, S., \& van der Sar, N. (1988). On the measurement and explanation of standards with respect to income, age and education. Journal of Economic Psychology, 9, 1-18.

Van Praag, B. M. S., \& Ferrer-i-Carbonell, A. (2004). Happiness quantified: A satisfaction calculus approach. Oxford: Oxford University Press.

Van Praag, B. M. S., \& Ferrer-i-Carbonell, A. (2010). Towards an urban quality of life index, basic theory and econometric methods. In E. De Lora, A. Powell, B. van Praag, \& P. Sanguinetti (Eds.), The quality of life in Latin American cities (pp. 65-90). New York: Inter- American Development Bank.

Van Praag, B. M. S., Frijters, P., \& Ferrer-i-Carbonell, A. (2003). The anatomy of subjective well-being. Journal of Economic Behavior \& Organization, 51(1), 29-49.

Van Praag, B. M. S., \& Kapteyn, A. (1973). Further evidence on the individual welfare function of income: An empirical investigation in the Netherlands. European Economic Review, 4(1), 33-62.

Publisher's Note Springer Nature remains neutral with regard to jurisdictional claims in published maps and institutional affiliations. 